\title{
Triggers of Spiritual Dryness - Results from Qualitative Interviews with Religious Brothers and Sisters
}

\author{
Arndt Büssing ${ }^{1,2}\left([) \cdot\right.$ Yvonne Beerenbrock $^{1} \cdot$ Mareike Gerundt $^{1,2} \cdot$ Bettina Berger $^{1}$
}

Published online: 9 June 2020

(C) The Author(s) 2020

\begin{abstract}
Religious persons may experience phases of spiritual dryness, ranging from spiritual insecurity to a spiritual crisis. The authors analyzed the underlying causes of spiritual dryness in religious brothers and sisters who had lived for several decades in monastic structures. They performed qualitative interviews with 16 brothers and 14 sisters and asked for triggers of phases of spiritual dryness. In the content analysis of the 30 narratives, the identified categories were inductively structured and condensed to five main topics: (1) Loss of Relationship with God, (2) Loss of Orientation, (3) Loss of Depth, (4) Difficulties with the Religious Community, and (5) Intrinsic Factors: Overload, Uncertainty, Depression. These five main topics can be further categorized as extrinsic (God is not responding, others cause difficulties) and intrinsic (loss of orientation and depth, uncertainty, and depressive state) causes. A thorough discernment of the underlying 'spirits' (the triggers) is important to help and support individuals during these phases. It seems that no single (theological) interpretation of the causes is correct but that different interpretations might be true for the very diverse persons experiencing these phases of darkness, dryness, desolation, or loss of faith.
\end{abstract}

Keywords Spiritual dryness · Desolation · Darknight · Depression · Religious brothers and sisters · Qualitative interview

Religious persons sometimes come to a point where all their quest and longing for God stalls, where they perceive that their relationship with the sacred has become shallow. Some experience that God seems to have completely left them, that their prayers seem to remain unanswered, that everything has become brittle, dry, and empty (Büssing and Dienberg 2019).

Arndt Büssing

Arndt.Buessing@uni.wh.de

1 Witten/Herdecke University, 583131 Herdecke, Germany

2 IUNCTUS - Competence Center for Christian Spirituality, Philosophical-Theological Academy, 48149 Münster, Germany 
Perceived abandonment by God, spiritual struggles, desolation, and desert experiences are classic themes in religious literature. One may find many interpretations of these experience, particularly expressed in the experiences of the mystics, who, despite sincere efforts to deepen their relationship with God, felt put into darkness and abandoned by God. Probably best known is the experience of the "Dark Night of the Soul" of John of the Cross (1542-1591) (John of the Cross 1959, vom Kreuz 2013). He described a spiritual purification process that is perceived as a painful phase of loss but that may nevertheless "cleanse" the God-seeker and throw him or her back to the pure essentials. Others argue that this 'Dark Night' is not a stage that has to be reached; it is neither a precursor nor a consequence of a certain spiritual state of maturity but can affect anyone (Cronk 1993). The theologian Karl Rahner (1904-1984) even considered this experience to be necessary for letting go of thoughts of one's own wisdom and power and all of one's own ideas of what God is. Then, one may perceive that "distance from God" is nothing but a vanishing of the world ("darkness") before the rise of God in the soul ("light") (Rahner 1993).

For theoretical reasons, two aspects should be distinguished: gloom (Finsternis) and darkness (Dunkelheit) (Büssing 2019). A gloomy darkening lacks the perspective of the coming morning, which is inherent in the darkness of midnight. If the first is a void that has lost every goal and purpose, then the second is a purification process that has God as its goal. In the gloom, the ' $I$ ' tries to control a desperate situation where depressive resignation prevails because the 'I' is caught in everyday life concerns and God is no longer the center of life. In contrast, the darkness includes the acceptance that God is still at the forefront; even if God is perceived as far away, God is still present as a trace and guides us in the darkness. One aspect leads to a distancing from God, and the other reminds us of the closeness that is still desired. However, darkness or spiritual dryness as a phase or even a process is not necessarily associated with emotional exhaustion and depressiveness but can be accompanied by these states. It is difficult to distinguish between gloom and darkness as the transitions can be fluid. Therefore, those who have experiences of darkness, spiritual dryness, desolation, etc., are probably at a crossroads that (if adequate support is lacking) can lead toward either spiritual despair and loss of faith or (if these are overcome) toward consolidation and spiritual growth.

In earlier empirical studies we analyzed how often phases of spiritual dryness (as measured with the Spiritual Dryness Scale; Büssing et al. 2013) were experienced. In Catholic priests, spiritual dryness was experienced often to regularly by $12 \%$ and as much as $46 \%$ (Büssing et al. 2017). In nonordained Catholic pastoral workers (women and men), $12 \%$ experienced spiritual dryness often to regularly and $48 \%$ sometimes (Büssing et al. 2016), while in religious brothers and sisters it was experienced by $14 \%$ often to regularly and by 55\% sometimes (Büssing 2019). The best predictors of phases of spiritual dryness are a low perception of the sacred in life and a low sense of coherence combined with depressive symptoms and emotional exhaustion (Büssing et al. 2017). The empirical data thus indicate that several factors, both psychological and spiritual, can cause phases of spiritual dryness.

For St. Ignatius of Loyola (1491-1556), spiritual desolation (i.e., feeling dry in prayer and distant from God) was a tempting of the Evil Spirit and a hint that something was wrong that should be changed (Ignatius of Loyola 1914). John of the Cross (1542-1591) saw the 'Dark Night of the Soul' as a process of spiritual purification in which God is calling the person (John of the Cross 1959, 1962). In contrast, the ascetic monk Evagrius Pontikus (345-399) wrote about an "inertia of the heart," a bored negligence termed 'acedia' that affected Christian 
hermits living ascetic lives in the desert (Pontikus 2007). As a consequence of this acedia, they experienced emotional fatigue and an inner emptiness, diminished attention in prayer, and tiredness in their life with God, which they might see as futile. Others discussed whether or not spiritual dryness is - in part - a depressive state (Bäumer and Plattig 2010; Durà-Vilà 2017; May 2003; Ott 1982).

Thus, there might be different factors that trigger phases of spiritual dryness, and so a conscientious distinction among these causes is important when persons experiencing these phases require support. We therefore aimed to interview religious brothers and sisters who had lived for several decades within monastic framework to identify self-reported causes and triggers of such phases of spiritual dryness. These narratives were analyzed based on the structuring content analysis methods of Philipp Mayring (2005).

\section{Methods}

\section{Study design and participants}

This study investigated the perception of spiritual dryness. To get open, experienceoriented narratives, we invited brothers and sisters from different congregations and performed semi-structured interviews. The participants were informed about this study through emails, either directly or to their community, or in the case of religious brothers through their superiors (who consented to this study). Those who experienced phases of spiritual dryness were invited to contact us to participate. Inclusion criteria were being a religious brother or sister, willingness to be anonymously interviewed, and informed consent. Sixteen brothers and 14 sisters expressed interest in being interviewed. We included all of them. To achieve a level of heterogeneity, we enrolled brothers and sisters from different congregations, from different age groups (relatively young and older), and from both large and small communities.

The study had two phases. In 2017 the religious brothers (14 Franciscan Capuchins, 2 Franciscans) were interviewed, and in 2019 the religious sisters were interviewed (6 Franciscan sisters, 1 Poor Clare sister, 3 Styler Missionaries (members of the Divine Word Missionaries), 2 missionary sisters of the Holy Heart of Jesus, 2 Dominican sisters). The mean age of the 16 religious brothers was 64.7 (range 35-87) years; the mean duration of affiliation in the community was 40.4 (range 7-67) years. The mean age of the 14 religious sisters was 65.3 (range 40-82) years; the mean duration of affiliation in the community was 37.4 (range 11-61) years.

\section{Semi-structured interviews}

The semi-structured interview started with basic information about the interviewee (i.e., age, duration of affiliation to the religious order) and then addressed five main topics: (1) living in a religious community, (2) perception of God's closeness, (3) experience of spiritual dryness (experiences, triggers, coping strategies, etc.), (4) social connectedness, and (5) generativity. For this analysis, we focused on the triggers of spiritual dryness.

All were interviewed in a place of their choice (usually a quiet room in their community). Average duration of the interviews was 50-60 min. The interviews were audio-recorded and professionally transcribed. 


\section{Data analysis}

A group of four scientists from the fields of health science/medicine, theology, and cultural science analyzed the German-language text material using qualitative content analysis techniques. The primary analysis began with the interviews of the religious brothers (phase 1), starting with an in-depth analysis of interview \#1 and the first codes. Then the next interviews were sequentially analyzed (with respect to meaningful text segments) and the set of codes was extended according to the new content. These codes were combined in a code list and grouped according to their motifs into main codes and subcodes. With this preliminary list, all interviews were reanalyzed and the code list adapted accordingly. Then, the interviews of the religious sisters (phase 2) were analyzed with the same procedure and the codes grouped in the code list of religious brothers where possible. New codes were added where appropriate. Finally, the interviews from phase 1 were reanalyzed using the adapted list of codes. Representative text passages served as anchor quotations for the respective codes (categories). Only the representative text passages used for publication were translated into English.

\section{Results}

During the process of content analysis, the identified categories were inductively structured and condensed to five main topics (see Fig. 1). These five main topics have a horizonal (others) and vertical (God) relational dimension and are presented as having either intrinsic or extrinsic aspects. These will be described with specific anchor code examples. To identify the interviewees we quote, we have used B for a brother and S for a sister, followed by the number of the interview within the group and then the line number(s) in the transcript. All these statements were responses to the topic of the interviewees' phases of spiritual dryness regardless of their length, including both short phases and long states.

In Fig. 1, a light gray background with black text represents a foremost extrinsic cause, while a dark gray background with white text is a rather intrinsic cause; a darker gray background with white text is a mixture of both.

\section{Loss of relationship with God}

Here, God is not perceived anymore; the person feels the loss of an already experienced closeness of God or lowers their expectation of God's closeness. The person is disappointed by God and perceives a distance from God. This topic refers to the vertical dimension.

\section{No perception of God}

One brother stated in a rather frustrated tone that he was convinced that there was a "personal God. But I [snorting] also have to say that I don't feel Him very much" (B1, 141-142). Another brother stated, "Yes, I don't feel anything. Yes. I do know that, too. I don't feel anything" (B3, 394). This perception was justified and compared to the long-term relationship of two married persons when "you may not feel anything anymore, too, it's much more a living side by side, right, and I don't think that's critical now" (B3, 396-400). 


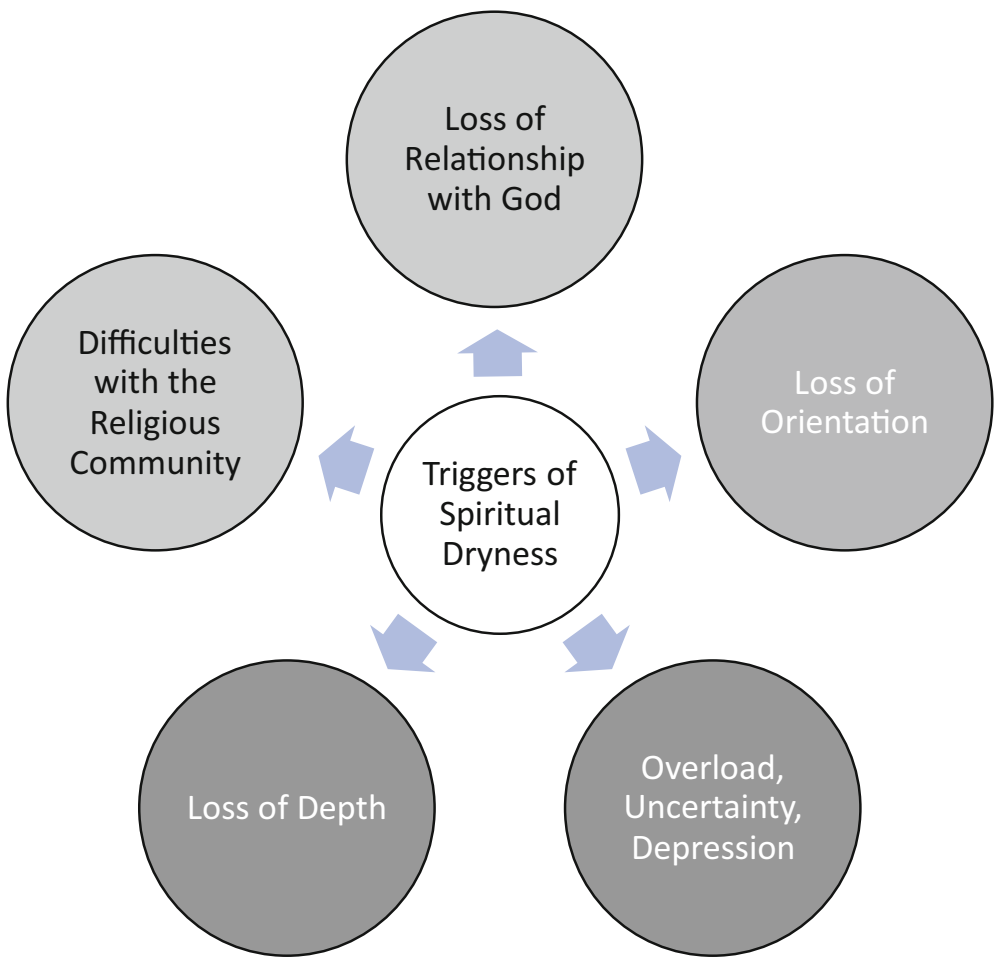

Fig. 1 Triggers of spiritual dryness (main categories)

One sister stated that she did not have a general feeling that she was not wanted by God, but nevertheless she felt that God was not speaking to her anymore: "That was only once at these retreats, where I really —yes, where is He, is He no longer speaking to me?” (S4, 286-288).

\section{Loss of an already experienced closeness of God}

This topic was mentioned by a religious brother who used the paired metaphors deficiency/ fullness, dark night/bright day, and valley/mountain highs to describe his relationship with God. Once he had experiences God's closeness, but now he was living in the absence of God: "Because, by suffering this deficiency, I long for the fullness-[corrects himself] I know that I long for the fullness. In suffering this deficiency, I do know that I am yearning for abundance. So, I couldn't suffer from the night if I didn't know the light" (B16, 537540). And further: 'I wasn't in this deep valley, yet, yes, of course I was! Yes, the deep valley didn't seem so deep to me, because I knew it was, so to say-I suffer from it, because I know the heights" (B16, 542-544).

This loss can be attributed also to one's own lack of effort, as one sister suspected: "I always have the feeling, yes, God is there, He is always there, and I am so far away from Him, and I don't bother enough, although I often find it difficult to really sit down for meditation or something, but I don't bother enough to keep this relationship right” (S9, 249-252).

The interviewees had different ways of perceiving this situation. Whereas the brother was watching his situation from a quite distant inner place, the sister was struggling with herself regarding the relationship. But both talked about a relationship they had had in the past. 


\section{No expectation of God's closeness/indifference}

In several cases, it seemed that the brother or sister had downgraded their expectation of being close to God because they actually did not perceive such a closeness. "Yes, I have to say that I am not so concerned that God has an answer for me. So, I do not expect God to give me a special - that I will have a special feeling that He is particularly close to me" (B1, 185-188). By comparing other persons' (better) experiences with his own, this brother withdrew himself emotionally: "There are gifted people who have the-who make the experience, yes, so, I interpret it like, 'God is especially close to me in this or that situation.' I don't have this- So, I don't have the urge for that" (B1, 188-191).

A similar reaction was found in another brother, who simply avoided dealing with the fact that his relationship with God seemed to be difficult, and thus he distanced himself from such feelings: "I don't put myself under pressure to always feel something. I don't think that's possible" (B3, 394-396). The statement of another brother pointed in a similar direction: "So I say, I have no expectation [pause] of this God that He should somehow do this or that." (B9, 169-171).

In terms of unanswered prayers (as communication), a religious sister said that she did not expect any answers because to her prayer was first of all being with God. This was a rather cognitive approach that might hide that she nevertheless expected closeness in her prayer life: "No answers to prayers I have not made a contract for this, I have to state quite succinctly, because I don't expect to get an answer to a concrete prayer, because it is for me Prayer is first of all being in front of God" (S5, 229-232).

\section{Disappointed by God}

Frustration and disappointment were important topics justifying the interviewees' difficult or even broken relationship with God. In an annoyed tone, one brother said: "There is also a dear God who soured on me - who hangs me, yes.. .. And that's what I ask myself: Where is the good God?" (B1, 146-147). A brother stated that his disappointment resulted in an active emotional withdrawal: "I felt disappointed with Him and I didn't care. And where I didn't really put much value on him. .. , yes, where he let me down" (B2, 199-203). In a similar way, a sister blamed God because He had turned away from her, not she: "But that was - I did not leave" (S14, 229).

A brother referred to his struggles and disappointment in God due to a difficult life situation: "And during that time, so, I was not only physically bad but also emotionally, because I also have argued with God and. .. I moved away from Him" (B2, 185-190). A sister also struggled with God because of a difficult life situation: "I had a period of struggle with God before I went to the monastery because my friend studied theology, and I found that God offended me, and then I went into a duel, but I lost" (S3, 207-210). She was frustrated after fighting with God without success.

Another sister talked about the frustration of not knowing what God expected of her and described the difficult situation: “'What should it be, God, now?' Then again, 'What do you want from us?"” (S12, 350).

\section{Alienation from God}

A brother stated that spiritual dryness is a matter of alienation from God: "I associate drought with alienation" (B16, 338), while another used the term distance to describe it: "That's kind of - God somehow seems a bit distant" (B3, 368). 
These perceptions have an impact on a person's sense of meaning in life and on their decision to live in a religious community, particularly when their relationship ("connection") to God is called into question: "Then, when I was in the Order, there was a phase where I might also be afraid - that my whole existence in God, in the Order, is called into question, because I somehow feel that I have no connection to God at all. That's where I fought" (S3, 210-215). In some situations, a sister was aware that God was no longer the focus of her prayer life and that she had lost her relationship with God: "All that concerns me is a spin, a self-talk with myself, even in prayer, I sometimes notice: 'Stop, stop, you're not in relationship'” (S13, 344-346).

Being disappointed in God can also result in feelings of distance, and one of the statements cited above is also an example of this category: "And during this time, so, I was not only physically bad but also emotionally, where I also had a strange quarrel with God and. .. I moved away from Him, but somehow, I could not get away from Him, and during this time, in this hopelessness, in this time of disorientation, I also felt this dryness, but, but somehow, I was unable to completely detach myself from Him" (B2, 181-190).

\section{Fighting with God/longing for God}

During these times of darkness, some persons may distance themselves from God while others are still fighting to get back in a close relationship: "And then, of course, I had to fight in my prayer life and say, 'God, I don't feel you anymore, show me another way, I want to be free'” (S2, 128-132). Another sister referred to this fighting as a process of liberation to come closer to God again: "So, I have what I call today this struggle with God, this not feeling with God, this struggle for liberation: 'Give me liberation from having to remain in this darkness for so long [sigh], let me go,' etc.” (S2, 139-143).

One sister clearly stated a constant longing to be reunited with God, even in her difficult times: "Well, I wouldn't see this as coercion-but as longing rather than coercion. Really as a deep longing to reunite and, yes." (S9, 193-196). This constant and unsatisfied longing for God's closeness was also addressed by another sister: "In this search-it can have a dryness. .. that I say, where do I keep searching, how do I get to Him now. I mean it's my turn, but why am I still searching? Then why am I still trying to find out something new about Him when Iwhen $\mathrm{He}$ is always there. Why am I trying to get to Him more clearly, through pictures, through a written word?" (S6, 522-528).

\section{Loss of orientation}

When persons lose their orientation in life, their function in a specific role, phases of spiritual dryness and struggles with God may be a consequence. The underlying subcategories here refer to a loss of spiritual orientation, self-doubt, uncertainty, and a need to reorient contradictory or changing images of God, sadness about the shrinking of the community, and loss of a life dream. The underlying triggers are intrinsic and also involve reactions to external processes. Interactions between the horizontal and the vertical planes can appear.

\section{Loss of spiritual orientation}

Times of despair and loss of orientation in life can be triggers of spiritual dryness, as one brother stated: "And in this time, in this hopelessness, in this time of disorientation, I also felt this dryness" (B2, 181-193). Or: "Yes, these phases are there, sitting in this deep valley and 
thinking, 'Oh, why should I orient myself to all this?' And also to experience how one does not orient. And then come back. Yes, it is painful" (B16, 355-358). A sister described her lack of clear orientation in this way: "And that was such a shaky time, where the question was, is this my way now, isn't it my way?" (S14, 181-183).

One brother identified the cause as his less focused lifestyle: "Well, I already know phases where you think, 'Now I have to arrange and sort something again,' that I'm a bit confused, so messy, so, not so focused on something, yes" (B8,278-281).

One sister missed a former duty that had given her orientation and meaning: "And I had a task over four years, it was really hard, and I had to realize that this is not mine. It was a very difficult time for me in this dispute" (S12, 323-325).

Another sister stated that the loss of her spiritual home in the community was part of the problem: "And since then I have fought and wrestled a little bit to find my way here again, also to find my spiritual home here again" (S9, 131-133).

\section{Perceptions of self-doubt and self-devaluation}

Loss of spiritual orientation could happen for various reasons, including self-doubt, uncertainty, and the subsequent need to reorient. This was addressed by a sister when she stated: "One of the worst reasons for such an experience of drought, of doubt, of no more knowledge: what else should I do now? This being in question and the question: Who am I really now, and is it really all like that? Those self-doubts that came back" (S6, 418-421).

Self-condemnation or devaluation of herself was a trigger in another sister: "Such selfconviction and thus confirmation of these inner devastating voices. And then I have the impression that it is difficult for me to remain in a tension of openness" (S13, 297-300).

One brother stated that his spiritual orientation was "broken" and thus his inspiration in life was gone: "My theology was broken - the conventional one - and it has not inspired me anymore" (B11, 91).

\section{Contradictory or changing images of God}

A significant struggle in the life of a devoted religious person can be the experience that their old views of God are not valid anymore: "I'm also sitting in this phase now, 'God, now show us, now give me - it must - this can't be. I need a different image of God"' (S2, 155-157).

One sister classified her current view of God as a result of her strict religious education in her youth but said it needed to be changed: "But the rigor has gone with us, the strict God, and he sees everything, and we have had a very strict upbringing and a lot of prayer and church. And in this I entered in my monastery, I already had - I also loved God, and in that time I felt very much, 'No, I must have a good God.' I had scruples, it can be said. And I had to fight inside" (S2, 117-122).

One sister experienced that her view of God had to be changed because God was more different than she had expected: "And then I started thinking, then I thought, and then all sorts of doubts and thinking came. I wanted to think of God. .. in any case, I suddenly became so clear, a God that one can think - there is no such thing, he is not a God" (S9, 137-142).

\section{Sadness about the shrinking of the community}

The shrinking of religious orders was for several a matter of frustration resulting in insecurity and doubts about their meaning and purpose in a changing world. One brother said: "Namely, 
this search for the right way, but also the inside of a great sadness that can arise, no doubt through this dryness in the religious world and through this shrinking process" (B6, 358-361). Or, as stated by a sister: "I was often sad that we are getting old and getting smaller and there are no more young ones or there are only a few" (S8, 350-351).

One sister also noted that the reduction in numbers is aggravated by the fact that several of the remaining younger sisters were leaving, and this impacted the future of their community and their order in general: "Or even this whole question, the future of our religious community, some women are leaving again, that was a deep crisis I slipped into. Not just me, but many of us" (S12, 345-347). Here, an interaction between the horizontal and the vertical planes appears: one's own spiritual orientation falters when the community dwindles.

\section{Loss of one's life dream}

For this inductively generated topic, two statements were found. One brother hoped to have a specific attractive assignment abroad but became severely sick overseas and had to return: "Now this dream has been fulfilled, but after five years it was nothing but a dream" (B2, 183184). This was a reason to fight with God who had interrupted his life dream.

A statement of a sister addressed the knowledge that she could not become a mother and pass life on, which caused some struggle: "I also had a phase like that, it was difficult because I was in my mid-thirties, suddenly I couldn't see a pregnant woman and go on living. She had life in her where she lived on afterwards and I didn't have that" (S10, 501-507).

\section{Loss of depth}

This topic addresses intrinsic processes that distract persons from religious practice because they are caught up in everyday business. The discipline is lost, the religious practices became boring routine, and they finally tend to escape from God.

\section{Remain on the surface}

Spiritual dryness was seen by one brother as the result of his own superficiality: "I've never seen it as an emptiness or a loss. But that could be related to the fact that I tend to go into superficiality and not really become aware of what I'm missing" (B7, 126-129). He became particularly aware of this after a retreat where the differences between time-out and routine days became evident: "Sometimes I notice it when I come back from a retreat or something like that, that I suddenly feel again something that was not noticed before, where I might have had an imbalance without feeling or not feeling it as a time of emptiness, but when I suddenly realize, 'Oops, you've been on the surface for a while now. It's good that you are coming back down now'” (B7, 129-135).

\section{Distraction from God through everyday business/no time for God}

Distraction from God or lack of time for God because of the demands of everyday life was addressed by several persons: "There is so much clutter that concerns me every day, and I'm busy with all this stuff, and then I don't necessarily ask, yes, no, where it comes from and where it goes" (B1, 214-219). Or: "I then worked so much, was thinking what - to make decisions and so on. And I have forgotten to make time for God" (S1, 195-197). 
Even the congregational prayer times become a distracting duty when one is absorbed by too much routine work: "So, sometimes we come close to prayer, maybe you should be there earlier, because you come out of work and are a little aroused inside by all sorts of things"(B8, 386-390). Or: "Well, either times when, I say, so many storms in from the outside that it is really difficult to really be there, even in quiet times or in prayer times, and that the head is already busy with ten thousand other things." (B9, 152-156).

During such times, one sister said that it was not God who was not present but she who was absent with all the extra duties; then God had to remind her that He was "still there": "No, God has never left me. It was rather the opposite, that I eluded [God] myself. For example, when I'm so superactive again, I whiz around for a long time, then He has to knock really hard and say, 'Hello, I'm still there"' (S1, 185-190).

One sister clearly recognized that all these activities are nothing more than a tendency to not confront God, to escape from God: "The other is flight. I know that very well, this going into work activities" (S12, 458-459). This insight may nevertheless cause feelings of guilt, too, which in turn aggravates a phase of spiritual dryness: "Or, I let myself be driven by my work and say, 'Don't have time,' because the other activities go along much better until the guilt comes back" (S9, 118-128).

\section{Loss of discipline/negligence}

Some experienced a lack of motivation or discipline to participate in the community and in congregational prayer life: "But that takes, yes, it takes discipline. This does not work by itself, I always have to pull myself together" (B8, 326-327), particularly when others are lazy, too: "And you suddenly find yourself in a fraternity, where only a few guys appear to pray together, then I think it will be difficult" (B14, 227-229).

A sister described a strong loss of motivation: “Occasionally, I didn't feel like working in there or looking for anything" (S3, 197-199), but she did not relate this lack of motivation to a phase of spiritual dryness: "I have phases of weariness and stuff like that. I wouldn't see that as spiritual dryness now" (S3, 204-205). This view was shared by another sister, who differentiated between the two states: "Well, let me put it this way, if dry time means no motivation, that happens-so everyone has no motivation at times, that's the way it is" (S5, 200-201).

Even in these phases with low motivation or loss of discipline, one sister noticed that God was still present but that she was neglecting Him and that this affected their relationship: "Then I always have the feeling that, yes, God is there, He is always there, and I am so far away from Him, and I do not make an effort, although it is often difficult for me to really sit down for meditation, but I'm not trying hard enough to keep this relationship going" (S9, 249-252).

\section{Boring routine}

The congregational prayer life is often seen as boring and thus not 'fruitful' for the relationship with God: "Sometimes I sit there in the Liturgy of the Hours and think, 'Oh, that's all horrible, how the brothers pray like that - and I'm actually just praying in the same way" (B10, 163166). Or: "Yes, of course. So, that's not always so alive, it definitely is not. So, dryness in that sense is already there" (B13, 171-172). 
The term 'dryness' was also used to refer to the daily religious 'routine' practices: "But if this and that is sung every day, and every service has to be sung - sometimes I no longer sing along because that's too much for me. And that's too dry for me" (S8, 185-187).

\section{Escape from God}

Several of the above-mentioned behaviors could be interpreted as a way to avoid God, as an act of self-withdrawal and escape. Several sisters clearly stated this: "No, God has never left me. It was rather the opposite, that I eluded [God] myself" (S1, 185-186); "And then I have the feeling that I quickly check off and flee into other things, yes, really, flee" (S9, 260-261); "The other is flight. I know that very well, this going into work activities." (S12, 458-459); "Oh, God, yes, you can still [Internet] surf a bit, google a bit, can read something nice [laughs], a kind of evasion" (S13, 263-264).

\section{Difficulties with the religious community}

Although the religious community and community life were described as beneficial and the structures as helpful in the interviews, several also mentioned difficulties with their community. Important causes of anger, pain, and spiritual dryness (expressed in many specific statements) was conflict, or even mobbing (bullying), within the religious community, no emotional resonance in the community, or difficulties with the expectations of others. This category refers to external triggers and has a clear horizontal direction.

\section{Conflicts in the community/mobbing}

Conflicts were reported quite often by both brothers and sisters, and in most cases the emotional pain and frustration was still present: "There were situations where I said, 'Now it's enough, now I'm going.'. .. I have experienced this more often because sometimes I have really experienced brothers who were anything but fraternal" (B5, 203-209). A sister interpreted patronizing by others as spiritual abuse: "When people or sisters talk to me and then put me down, uh, sometimes I think, 'Well, that's already on the verge of spiritual abuse"" (S2, 183-185). She felt that she was driven into the role of a "victim," which caused her emotional pain: "Then I lived somewhere, where I was always shouted at by a nun, then I was the victim" (S2, 356-358). Another sister mentioned a specific person who constantly annoyed her, causing emotional disturbance she was unable to deal with: "I still had periods where I-and that is really often the case - that it was difficult in the Convention then, and a fellow sister annoyed me so much, and I know that's my trigger point, but I couldn't turn it off, and every day, even if she just took a breath, and I-inwardly I thought, Oh, no.” (S3, 238-242).

Another sister attributed her phases of spiritual dryness to the community: "This feeling, yes, the dryness, the futility of my life, is actually, strangely, never from God but from the external circumstances, I would like to say. So, rather, people who have hurt me, who have deeply pushed me, the external circumstances" (S4, 281-283). Another sister mentioned her inability to deal with such situations: "When it comes to spiritual dryness, there are situations where I do not know where it is - where I am in a situation where my hands are mostly humanly bound. So it's often in the dryness, for me at least, because it's about me being in an interpersonal situation where I no longer know how to proceed" (S6, 358-365). 
Conflicts within their community made some think about leaving the community: "But really serious was this great conflict that I had with this brother. I thought, 'Well, now I'm really going"" (B10, 322-324). Some conflicts were so dramatic that suicidal thoughts arose: "There was a fellow brother who drove me into a suicide attempt, who bullied me to such an extent that I, so, really stood at the window" (B16, 599-600).

\section{No resonance with the community}

Even among others who may share the same values and religious attitudes, persons may feel lonely, misunderstood, or without emotional support: "Where you might feel a little bit like having no resonance, feeling misunderstood, or maybe not being the right people in the Convention, and you feel single, on your own" (B7, 117-120). Or: "And the hardest thing for me was that the other sister always reacted as if she didn't know what I was talking about. 'Why, everything's fine,' and I thought I was in the wrong movie. That totally finished me off' (S3, 225-228).

The inability to understand the situation or feelings of others is of course two-sided, and their own attitudes and behaviors could be the cause of their feeling unable to meet the expectations of others, as one sister said: “. . . a non-understanding of the others, so that I cannot understand the others. . . . I got the job from you [the other sisters], I can't do it better. And where human jealousy plays along like this, which I experience very strongly, or where there are expectations that I cannot meet, cannot fulfill" (S6, 301-305).

One sister clearly attributed the cause of her phases of spiritual dryness to such experiences of different attitudes, perspectives, and expectations: "And that was actually such a reason for this - this dryness that I sometimes couldn't understand why others see it differently. And that they don't believe me, or that they don't trust my life experiences"' (S6, 412-415).

Such experiences might cause brothers and sisters to reconsider whether their decision to live in the community was in fact right or whether they had to significantly change things in their life: "The triggers [of spiritual dryness] are usually interpersonal conflicts. And they tend to lead me to say, 'How I want to live doesn't work here in this community' (B10, 223-226). Or: "Especially when you feel, 'Oops, this is where priorities shift. What really is the core of a religious life?"' (B14, 219-221). Or: "If you have such a low period and you think, 'No, well, now I'm done with the task here and with the community, that's enough for me now!' . . yes, then, another place, other people" (B3, 338-341).

Finally, one sister described feeling completely alone and that no one would come to her aid: "Sometimes I feel that way, when you're at the bottom, you think, 'Where are the people who are with you now? I need someone now, but there is no one there.' So, this experience, you live in a community with like-minded people, but there is no one there. Nobody just notices how badly you are doing" (S12, 430-432).

Emotional loneliness even when among others as a trigger of spiritual dryness may also change a person, as stated by one brother: "The dryness itself, I have always experienced it in these phases, where I felt a bit lonely and abandoned.. .. Maybe that's why I've gotten a little more serious. I don't know. But I resist being a joyless person. So, I certainly am not" (B5, 150-154).

A consequence of lacking resonance with or trust in others living in the community might also be that the relation to God becomes dry, as suggested by a sister: "And I have, yes, if I don't have more trust in people, I also lose confidence in God a little bit, that's just the way it is. And then I have this dryness" (S2, 259-260). 


\section{Difficulties with the expectations of others}

One sister stated that a cause of her spiritual dryness was that she could not deal with the expectations of others, which also caused jealousy because she felt unable to fulfill the expectations of others: "Where one perceives that - the non-understanding of others, so that I cannot understand the others. Why are you now-I got the job from you [the other sisters], I can't do it better. And where jealousy plays along like this, which I experience very strongly. Or where there are expectations that I cannot meet, cannot fulfill" (S6, 301-305). Finally, she felt betrayed by the others: "Where I said, 'Why are you asking me to do this now?' And I was unable to reach the others and also partially - maybe even, I just say now with a somewhat strong term- -have felt betrayed" (S6, 392-394).

\section{Intrinsic factors: Overload, uncertainty, depression}

This topic combines several motifs that could be related (in part) to depressive states of emotional exhaustion or personal uncertainty. These were regarded either as causes of spiritual dryness or as accompanying perceptions and feelings (side effects). This category was generated in the second phase of the study; interestingly, most of these statements are from religious sisters. This topic has an intrinsic aspect that might of course be further triggered by external causes.

\section{Overload}

Stress and work demands can be, as stated above, causes of spiritual dryness, particularly when the person's own spiritual resources fall short: "There are certainly times like this in everyday life when it is so stressful and the demands of work and so on become so overwhelming, then the prayer life also - then this becomes shorter or then also fails, and then there is, 'Yes, what's the point here, and it doesn't bring anything, and why did I go to the monastery in the first place, just so that I would work 13, 14 hours a day, what's the point of that?' That's always there" (S4, 263-270). This cause of spiritual dryness was clearly attributed to the work stress, not to God: "This feeling, yes, the dryness, the futility of my life, is actually, strangely, never from God, but from the external circumstances, I would like to say.. .. Overloaded with work" (S4, 281-288).

Lacking self-care abilities seems to be one of the problems: “.. . that one no longer takes care of oneself, that one finds nothing that is important for oneself, but expends oneself completely and then gets into such a time. Because you haven't paid attention to yourself anymore" (S6, 380-383).

\section{Doubt/uncertainty}

Specific personality structures may facilitate experiences of spiritual dryness, particularly selfdoubt and uncertainty. This was stated by one sister: "I think that was one of the worst reasons for such an experience of dryness, of doubt, of no longer knowing: 'What else should I do now?'. .. These self-doubts, which then just came back" (S6, 418-421). Or: "Perhaps I have often not been self-sufficient enough and have always thought that I have to look at what others say or do, and that was certainly a mistake, because I then let myself be unsettled by others. And I've been working on it for years, I have to say. And-I've struggled for years" (S7, 208-213). 
Even severe doubts about the person's own faith and thus religious life were prevalent: "These are sometimes moments when I think, 'Is this really all true? Or is our Christian faith a fantasy?' So sometimes it's like cracks, where I think it's maybe not true” (S13, 317-319).

\section{Depressive states}

One sister recognized that spiritual dryness might be a state of depression: "Later, I had another phase, it was like such a dead desert, it didn't matter. I felt like I was in a depression.. .. I knew that this was a depression, that's still the feeling for me to this day.. .. It all came together, and it was like the desert. Dry earth, there was nothing going on. And that has gone on for years" (S3, 171-180).

Others were less clear about such states but described similar things: "So, especially this spring, when it takes a lot of strength to get me up, 'So I have to do that,' or where I push everything back that is personal. Yes, I had such a phase now in the spring, exactly. It was all so dull. And then confirmed, then it turns inward, oh, woe" (S13, 308-312).

Another sister uses the metaphor of 'night' (referring to John of the Cross's 'Dark Night of the Soul) to describe it: "So when the talk of night is, yes, it was not just night, but it was just black and dark, and of the feeling that was before, of everything was megasuper - there was nothing left.. .. That was really the feeling of total cutoff. And of-yes, somehow, there was nothing left" (S14, 132-139).

\section{Inner emptiness}

Depressive states might also be related to feelings of inner emptiness, which may cause or aggravate phases of spiritual dryness. One sister said: "And that probably led me to a void, to an inner struggle, to an inner "Where are you?"' (S2, 132-134). Or: "Dryness is for me such a lethargy, such a, yes, nothing happens inside anymore, so it doesn't go inward, it doesn't go outside, it's like stagnation, it's such a stop, and a lot of things don't tell me anything anymore" (S13, 257-260).

One brother stated that during these times of inner emptiness even participation in congregational prayer times is difficult: "So. .. an effect in a time when there is rather emptiness is also so that choral prayer and prayer times and similar things are difficult" (B9, 187-189).

\section{Inner restlessness}

The opposite might also be true, when a person perceives that something is missing, that the void needs to be filled with something positive. A specific symptom could be "inner restlessness": "Yes, [it] is the case with me that-I am driven by such an inner restlessness. I can no longer just sit there quietly for meditation. I then have such a restlessness and, yes, go out into nature and say, 'Dear God, you are there too,' and — or let me drift away from my work and say, 'Don't have time,' because the other things are much better for me, until the feelings of guilt come back (S9, 118-123). And further: "Then I just go, that's my experience, then I run, then I run away, then I'm driven by a restlessness and then I run to work or run, yes" (S9, 155-157).

\section{Discussion}

Within the narratives of the 30 brothers and sisters, we identified five main triggers of spiritual dryness: (1) Loss of Relationship with God, (2) Loss of Orientation, (3) Loss of Depth, (4) 
Difficulties with the Religious Community, and (5) Intrinsic Factors: Overload, Uncertainty, Depression. These came up during the interviews when they talked about how they perceive such phases and their causes. The five main topics can be further categorized as extrinsic causes (God is not responding, others cause the difficulties) and intrinsic causes (loss of orientation and depth, uncertainty, and depressive states). It seems there is not one cause but several, depending on the life situation and a person's attitudes, perceptions, and behaviors.

As stated above, St. Ignatius of Loyola attributed spiritual desolation to a tempting of the Evil Spirit. In his exercises, he writes about "spiritual desolation" which is associated with a "darkness of soul" and is characterized by a state "without hope, without love, when one finds oneself all lazy, tepid, sad, and as if separated from his Creator and Lord" (Ignatius of Loyola 1914, Fourth Rule). This state is seen as a "trial. .. in order to resist the different agitations and temptations of the enemy" (Ignatius of Loyola 1914, Seventh Rule). He meant an external evil spirit (“devil”), but we were unable to identify participants in our study who claimed this. However, if we interpret this as a hint that one's own focus ("spirit") was driven away from God and that one should change that what went wrong (i.e., one's mindset), then we can find several examples, particularly in the category Loss of Depth (i.e., loss of discipline, not enough time with God, too much routine work that distracts from religious practices, boring religious practices, remaining on the surface, etc.). These topics would also fit the idea of the desert fathers' bored negligence, which was personalized as the 'noonday demon' (acedia). To the desert fathers, the most difficult time of day was noontime, when the day seemed too long and boring, when they would look for something more attractive than their religious practices. This distracting mindset (spirit) can be found in the statements of various of the brothers and sisters interviewed here. A modern interpretation would be that the (intrinsic) mind has lost its focus and is thus more susceptible to seductive (external) influences that distract from God.

Another interpretation that was often mentioned comes from John of the Cross, who regarded the dark phases as a process of spiritual purification with God as the 'light' and the attractor (John of the Cross 1959, 1962). The first step of this process refers to a purification of the senses (as a dark night of the senses) to let go of worldly desires (John of the Cross 1962). Within the narratives of our interviewees, we were unable to find clear examples that pointed in this direction. Rather, we found examples of the loss of the perceived closeness of God, the loss of a previously perceived closeness, etc., which would at least fit with the interpretation that God withdraws so that only pure longing remains.

Such a longing for God was indeed an exclusive subcategory as part of the main category Loss of God. The loss of God's closeness is perceived while the longing is still there ("Because by suffering the deficiency, I long for the fullness" (B16, 538-539). Another perceived that she had distracted herself from God, not God from her ("I always have the feeling, yes, God is there, He is always there, and I am so far away from him" (S9, 249-250). When this longing for God is the crucial point for enduring the process of spiritual dryness, some brothers and sisters reported either being disappointed by God or not expecting to be close to God at all. The latter argument could be also a matter of self-protection because they could not perceive God's closeness in their life as a religious person, which caused frustration and doubt about their chosen life as a religious person. Avoiding dealing with the fact that their relationship with God was difficult, some distanced themselves from God and thus from feelings of abandonment as well. It seems that some had lost (at least during these phases) this longing for God, which would indicate they had established themselves in the routine of everyday life and expected nothing more. 
Both empirical studies (Büssing et al. 2016, 2017) and also theological and psychological/ psychiatric reflections (Bäumer and Plattig 2010; Durà-Vilà 2017; May 2003; Ott 1982) have identified depressive states as a cause of spiritual dryness. Different aspects of depression were indeed found in the texts we analyzed and were condensed in the category Intrinsic Factors: Overload, Uncertainty, Depression. It was not our aim to determine whether the interviewees had a clinical diagnosis but to identify motifs that could be attributed to depressive states. All the brothers and sisters seem to have found ways to deal with these phases of spiritual dryness; only a few reported a long-lasting state. Nevertheless, the subcategories Overload, Doubt/ Uncertainty, Depressive States, Inner Emptiness, and Inner Restlessness clearly point to intrinsic causes related to personality structure. Such perceptions are not exclusive to Catholics but can also be found in persons from other denominations. Ellen G. White (1827-1915), one of the founders of the Seventh-day Adventist Church, reported difficulties praying and resonating with God and others, and she also experienced symptoms of exhaustion. She wrote: "None knew my labor or burden of mind as I united with the family in morning and evening devotion, and sought to lay my burden upon the great Burden Bearer. But my petitions came from a heart wrung with anguish, and my prayers were broken and disconnected because of uncontrollable grief' (White 1868, 1 T 576.2).

Some of the brothers and sisters with indicators of Overload, Uncertainty, Depression analyzed here might be more responsive or vulnerable to external triggers (including interpersonal conflicts), while others were better able to distance themselves. In fact, Difficulties in the Religious Community was an exclusive main category that was so far not explicitly discussed in this context. For this category, we found several examples, not only of 'simple' conflicts or misunderstandings with brothers or sisters (which might nevertheless be hurtful and result in anger and frustration) but also more serious ones such as mobbing (leading to suicidal thoughts, as stated by one brother) and spiritual misconduct (as stated by one sister). Interestingly, John of the Cross had severe struggles with his Carmelite brothers, too, who imprisoned him in the dark to punish him. During this stay in a dungeon, he experienced his 'dark night' as a way of inner liberation.

Another important subcategory, contradictory or changing images of God, refers to a process of religious 'maturation' in which brothers and sisters noticed that their former views of God were either dysfunctional or interpreted them as not adequate or not helpful and had to be adapted to become a loving God. The 'otherness' of God is also a relevant topic in theology and was mentioned by a sister who attributed her phases of spiritual dryness to "wrong" views of God but recognized that a god "one can think" is not the true God (S9, 141-142). This is similar to the views of John of the Cross, who regarded the Dark Night of the soul as a purification and also development process where one has to let go of the old view that throughout life God is comforting us at God's "mother's breast" (John of the Cross 1909, Stanza XXII: 10). Instead, one has to let go of all these 'secular' thoughts and face God in his 'otherness' ("I am who I am," Exodus 3:14). This describes a process of transformation of the soul toward a "spiritual union" with God, detached "from all things and from self," where the soul "is in solitude, spiritually detached, which takes place when all the desires are quenched" (John of the Cross 1909, Stanza XXII: 10).

In contrast, Loss of Resonance with the community has an attributed external reason but an intrinsic motivation. The interviewees' brothers or sisters were not perceived as suitable partners who could understand or resonate with the concerns of the person living with them. The composition of personalities in the community is not a chosen one, and also in religious communities one has to find people who can understand and support one. When these persons 
are lacking, it may lead to loneliness, inner withdrawal, and feelings of meaninglessnesswhich may be interpreted as a depressive state. The problem of lacking resonance might also refer to distinct types of characters and their ability to engage with other people.

One of the predictors of spiritual dryness found in an empirical study was lack of a sense of coherence. Antonovsky $(1979,1987)$ defined this as a triad of comprehensibility (i.e., that situations make some sense and are ordered), manageability (i.e., that persons perceive they have the resources to cope with difficult situations), and meaningfulness (i.e., that life makes sense and is still worth it). In the narratives of brothers and sisters, we could identify at least some topics that might fit this health concept, i.e., Overload, Inner Emptiness, Loss of one's life dream, sadness about the shrinking of the community, etc. Here, everything is perceived as too much to handle, one is disappointed by God who is not responding anymore, and one considers letting it all go and leaving the convent-or continuing without inner empathy. In fact, it is not surprising that a low sense of coherence is a predictor of depressive symptoms, as reported by Larsson and Kallenberg (1996) and Carstens and Spangenberg (1997). Both may thus contribute either as enabling factors in terms of higher susceptibility or as a direct cause of spiritual dryness.

The distinction between the intrinsic and extrinsic dimensions corresponds to the two main states of the dark night as described by John of the Cross: the Dark Night of the Senses and the Dark Night of the Soul (John of the Cross 1962). He described the 'senses' as the pleasure found in worldly pleasures and joy that were taken away to initiate a detachment from this (external) joy, to emotionally liberate the soul on its way to unification with God. The first dark night, the Dark Night of the senses, is a consequence of regular spiritual practice and serious spiritual discipline. As the interviews show, a turning away from daily spiritual practices (Loss of depth) does not seem unusual. In this phase, unpleasant feelings seem to arise from the depths, clouding the feeling of being with God. Where once in spiritual practice the answer was God's love, joy, and sweetness, the passive Dark Night of the Senses results in spiritual dryness with feelings of emptiness, sadness, and frustration and maybe bitterness. Those who maintain faith and thirst for God may no longer find God's consolation in spiritual practices, regardless of how disciplined they are. In John of the Cross's interpretation, this Dark Night of the Senses could be triggered precisely by the deepening practice of prayer and intense spiritual practices (fostered by a life in an order) since through spiritual purification increasingly suppressed feelings may come to the surface, feelings that once formed the 'I' (identity) and to which the 'I' still clings. But these need to be shaken off in this Dark Night of the Senses to prepare the 'I' for the Dark Night of the Soul. The Dark Night of the Senses is a passive purification because God works from outside (external factors: Overload, Difficulties with the religious community) to trigger this first night. The duration of this first night is individual and seems to depend on the intensity of the required emotional release. When the first night is over, a more spirit-centered identity seems to emerge, one that now seems to be part of God.

The second dark night described by John of the Cross (1959), the Dark Night of the Soul, has as its insignia the uprooting of the self through the purification of the soul from the projections and prejudices that create the 'I' and hinder the union with God, resulting as well in spiritual dryness, difficulty concentrating, and confusion (intrinsic dimension: Loss of Orientation, Insecurity, Depression). This Dark Night of the Soul serves to purify one from a selfconcept that projects identity-forming meaning into one's own existence but deprives the True Self of the realm of being in God. For some, both the Night of the Senses and the Dark Night of the Soul continue for years at low intensity without their lives being significantly disrupted. 
Others have clear and classic episodes of purification, and most are somewhere in between. Based on the results of this study, we can assume that each person's journey through the 'Dark Nights' may be a lifelong, winding road.

\section{Limitations}

The findings were derived from Catholic brothers and sisters living in Germany. It might be that the perceptions of religious people from other countries are different inasmuch as further categories or subcategories could be found. It is currently unclear how lay people or religious persons from other denominations (who experience phases of spiritual dryness, too) would assess the underlying causes of spiritual dryness.

\section{Conclusions}

The resulting model of spiritual dryness (see Fig. 1) has different layers, first an intrinsic and an extrinsic direction of causes, second a vertical and a horizontal dimension of relations, and finally the different categories as identified in the narratives of the interviewed brothers and sisters. A thorough discernment of the underlying 'spirits' (triggers) is important to help and support persons during these phases. It seems that no single theological interpretation of the causes is correct; different people might experience these phases of darkness, dryness, desolation or loss of faith as having various causes. Further results of this study, particularly on the strategies the brothers and sisters have developed to cope with and overcome these phases, are currently in preparation.

Authors' contributions $\mathrm{AB}$ designed the study and wrote the first draft of the manuscript. The interviews were performed by $\mathrm{AB}$ and $\mathrm{MG}$. $\mathrm{AB}, \mathrm{YB}, \mathrm{MG}$, and $\mathrm{BB}$ analyzed the text material. All authors commented on draft versions of the manuscript and have read and approved the final manuscript.

Funding Information Open Access funding provided by Projekt DEAL.

\section{Compliance with ethical standards}

Conflict of interest The authors disclose no conflict of interest.

Open Access This article is licensed under a Creative Commons Attribution 4.0 International License, which permits use, sharing, adaptation, distribution and reproduction in any medium or format, as long as you give appropriate credit to the original author(s) and the source, provide a link to the Creative Commons licence, and indicate if changes were made. The images or other third party material in this article are included in the article's Creative Commons licence, unless indicated otherwise in a credit line to the material. If material is not included in the article's Creative Commons licence and your intended use is not permitted by statutory regulation or exceeds the permitted use, you will need to obtain permission directly from the copyright holder. To view a copy of this licence, visit http://creativecommons.org/licenses/by/4.0/.

\section{References}

Antonovsky, A. (1979). Health, stress and coping. San Francisco: Jossey-Bass.

Antonovsky, A. (1987). Unraveling the mystery of health: How people manage stress and stay well. San Francisco: Jossey-Bass. 
Bäumer, R., \& Plattig, M. (Eds.). (2010). Dunkle Nacht und Depression: Geistliche und psychische Krisen verstehen und unterscheiden [Dark night and depression. Understand and distinguish spiritual and psychological crises]. Ostfildern: Grünewald.

Büssing, A. (2019). Geistliche Trockenheit bei Seelsorgern und Ordens-Christen [Spiritual dryness in pastoral workers and religious]. In A. Büssing \& T. Dienberg (Eds.), Geistliche Trockenheit: Empirisch, theologisch, in der Begleitung [Spiritual dryness: Empirically, theologically, in the accompaniment] (pp. 79-103). Münster: Aschendorff.

Büssing, A., Baumann, K., Jacobs, C., \& Frick, E. (2017). Spiritual dryness in Catholic priests: Internal resources as possible buffers. Psychology of Religion and Spirituality, 9, 46-55.

Büssing, A., \& Dienberg, T. (Eds.). (2019). Geistliche Trockenheit: Empirisch, theologisch, in der Begleitung [Spiritual dryness: Empirically, theologically, in the accompaniment]. Münster: Aschendorff.

Büssing, A., Frick, E., Jacobs, C., \& Baumann, K. (2016). Spiritual dryness in non-ordained Catholic pastoral workers. Religions 7, 141. https://www.mdpi.com/2077-1444/7/12/141/pdf.

Büssing, A., Günther, A., Baumann, K., Eckhard, E., \& Jacobs, C. (2013). Spiritual dryness as a measure of a specific spiritual crisis in Catholic priests: Associations with symptoms of burnout and distress. EvidenceBased Complementary and Alternative Medicine., 2013, 1-10. https://doi.org/10.1155/2013/246797.

Carstens, J. A., \& Spangenberg, J. J. (1997). Major depression: A breakdown in sense of coherence? Psychological Reports, 80(3, Pt 2), 1211-1220.

Cronk, S. (1993). Darknight journey: Inward re-pattering toward a life centered in god. Wallingford: Pendle Hill.

Durà-Vilà, G. (2017). Sadness, depression, and the dark night of the soul: Transcending the medicalisation of sadness. London: Jessica Kingsley.

Ignatius of Loyola (1914). The spiritual exercises of St. Ignatius of Loyola (E. Mullan, Trans.). New York: Christian Classics Ethereal Library. http://www.ccel.org/ccel/ignatius/exercises.html.

John of the Cross. (1962). Ascent of Mount Carmel (E. A. Peers, Trans.). New York: Christian Classics Ethereal Library. https://ccel.org/ccel/j/john_cross/ascent.html.

John of the Cross. (1959). Dark night of the soul (translated by E. Allison peers). New York: Christian Classics Ethereal Library. https://ccel.org/ccel/j/john_cross/dark_night.html.

John of the Cross. (1909). A spiritual canticle of the soul and the bridegroom Christ (translated by David Lewis). New York: Christian Classics Ethereal Library https://ccel.org/ccel/j/john_cross/canticle.html.

Larsson, G., \& Kallenberg, K. O. (1996). Sense of coherence, socioeconomic conditions and health. European Journal of Public Health, 6(3), 175-180.

May, G. G. (2003). The dark night of the soul: A psychiatrist explores the connection between darkness and spiritual growth. San Francisco: HarperOne.

Mayring, P (2005). Qualitative Inhaltsanalyse. Grundformen und Techniken. Weinheim: Springer.

Ott, E. (1982). Depression?Die dunkle Nacht der Seele. [Depression? Dark night of the soul]. Steinbergkirche, Germany: Novalis.

Pontikos, E. (2007). Über die acht Gedanken [The eight thoughts]. Beuron: Beuroner Kunstverlag.

Rahner, K. (1993). Meine Nacht kennt keine Finsternis [My night knows no darkness]. Freiburg: Herder.

vom Kreuz J. (2013). Die Dunkle Nacht: Vollständige Neü̈bersetzung [The Dark Night: Complete new translation]. (11th ed.). Freiburg: Herder.

White, E. G. (1868). Testimonies for the church I (1T 576.2). Mountain View: Pacific Press.

Publisher's Note Springer Nature remains neutral with regard to jurisdictional claims in published maps and institutional affiliations. 